\title{
The Irish women's movement: from revolution to devolution
}

Connolly, Linda; Palgrave, Basingstoke and NY, 2002, £50 (Hbk), ISBN: 0-333-77132-X

\section{The Irish women's history reader}

Hayes, Alan and Urquhart, Diane (eds); Routledge, London and NY, £14.99 (Pbk), ISBN: 0415-19914-X

\section{In their own voice: women and Irish nationalism}

Ward, Margaret (ed); Attic Press, Cork, 2001 (first published 1995) €10.15 (Pbk), ISBN: 1$85594-101-5$

The study of women in Irish society, past and present, remains an important and challenging project. Although the voices of Irish women can be characterized as 'emerging' (0'Connor, 1998), much remains to be done before Irish women, as subjects of research and study, can be said to have been brought 'in from the shadows' (Lentin, 1995). The three books reviewed here offer the reader a taster of what has been achieved but each adds to the call for more research and for increased diversity in that research.

There is a welcome reprint for In Their Own Voice, edited by Margaret Ward. Ward has collected a variety of 'voices' - public, private and always political - from Irish women involved in the Irish independence movement in the late nineteenth and early twentieth centuries. As such, it represents both a chronology of events and from the perspectives of the women involved. Their determination, political commitment and forbearance through the deprivations (physical, political, ideological) of the struggles for Irish independence shine through the individual pieces collected here. This book illustrates the rich seams of history that can be mined through seeking women's perspectives on the events in which they participated and commented on. In her introduction, Ward acknowledges the particular focus of the book, and argues that there remain many gaps to be filled: 'we also want to know what women from all the different religious, political and social groups thought about all those important everyday issues that affect us all' (p. 1). The acknowledgment that Irish women's history remains largely untold is a concern shared by the other two books reviewed here.

However, The Irish Women's History Reader, edited by Alan Hayes and Diane Urquhart, indicates how much the study of Irish women's history has achieved, while also illustrating how much more there is yet to explore. It offers a range of definitive pieces, including a section on historiography, which grounds both this edited collection and provides a useful contextualisation of the study of Irish women's history. Women's places in the family, their participation in education and politics are all examined here. There is also a welcome section on Irish women and emigration. As such, the collection offers the reader and student an insight into 
many different aspects of Irish women's lives, and points to the work that remains to be done. The main gap in this edited collection arises from the focus on the nineteenth and early twentieth century - but as the editors point out, this is for practical reasons, given the paucity of writings on Irish women in earlier times.

Linda Connolly's book is the culmination of research publicised in her contribution to Women and Irish Society. That chapter shared a similar title to the book reviewed here and similarly argued that much of the study of the women's movement in Ireland was based on 'speculative observation from the outside' (Connolly, 1997: 553), a troubling sentiment repeated in the concluding remarks of the introductory chapter (p. 54) and in her critique of others' approaches to the study of Irish women inside and outside Ireland.

Nevertheless, this is an important, and interesting, if also challenging, book. Connolly is intensely engaged with her argument - that by examining the history of Irish women through the lens of social movement theory, one arrives at a story of continuity rather than discontinuity. To support this thesis, she develops the concept of 'abeyance organizations'. Neither of the abeyance organizations discussed - the Irish Housewives Association and the Irish Country Women's Association - could be termed feminist, but they represent a link of continuity between first- and secondwave Irish feminism if, as Connolly argues, an 'inclusive definition of the historical women's movement' (p. 79) is employed. This inclusive definition, however, does not appear to include Irish nationalism (although there is a small section on Irish Women United) and, in this sense, the subtitle from revolution to devolution is misleading if clever since it refers to the time frame covered by the book. Connolly argues that the 'grand narrative' of Irish history - and the debates over revisionism - has overly dominated the study of Irish women. Yet, as the work of scholars such as Margaret Ward shows (in the book reviewed here and her other work), this is a rich and important aspect of Irish women's lives, past and present, and an area where much remains to be done. The reclaiming and retelling of women's roles in the grand narrative, and the examination of the plurality of their participations and politics, stands as an important and essential corrective.

Connolly is particularly strong on second-wave feminism and the interviews with participants offer an insight in to the debates and struggles of the day. The examination of the struggle over abortion is forensic in its insight and analysis. Connolly, in common with Emily O'Reilly (1992), rightly labels the so-called 'pro life' movement as a counter-right movement which seized an opportunity by preempting feminist debate on abortion; right-wing idealogues laid down and defined the parameters of the debate, stifling the emergence of a feminist discourse on this central but highly divisive subject. In her analysis, Connolly identifies the emergence of a counter movement in Ireland as evidence of the success of the Irish women's movement: 'this counter movement would not have mobilised extensively unless there had been a perceived threat to traditional values in Irish society' (p. 179). Despite her gloomy prediction that the setbacks in the 1990s for the 
counter movement could lead to increasing militancy as in the USA, Connolly's book is to be welcomed for its upbeat, optimistic reassessment of feminism and the women's movement in Ireland.

Taken together, these three books illustrate the advances in the study of the histories of women in Ireland. They offer an interesting representation of the stages reached in the project of reclaiming and retelling Irish women's histories. They also reveal some of the different and differing approaches to those histories, and the continuing debates over Irish feminism and its roles and meaning in Irish society. What they share in common is the call for more research, analysis and debate on Irish women and their places and roles in Irish society. In this sense, they reflect Irish feminism itself, often divided but united in the cause of Irish women.

\section{Sarah Morgan}

\section{references}

Connolly, L. (1997) "From revolution to devolution: mapping the contemporary women's movement in Ireland". In M. Leonard and A. Byrne, (1996) editors, Women in Ireland: A Sociological Profile, Belfast: Beyond the Pale.

Lentin, R. (1995) editor, In From the Shadows: the University of Limerick Women's Studies collection, Limerick: UL.

O’Connor, P. (1998) Emerging Voices, Dublin: Institute of Public Administration.

O’Reilly, $\boldsymbol{\varepsilon}$. (1992) Masterminds of the Right, Dublin: Attic.

doi:10.1057/palgrave.fr. 9400148

\section{The power to choose: Bangladeshi women and labour market decisions in London \& Dhaka}

Naila Kabeer; Verso, London and New York, 2000, ISBN: 1859848044

Naila Kabeer's book was published in 2000, but its contribution to current ethnicity, gender, development, economic and socio-cultural debates is still entirely relevant. Although the book's scope is more wide-ranging than her previous work, Reversed Realities: Gender Hierarchies in Development Thought (Verso, 1994), it theoretically and methodologically builds on her earlier study in its engagement with and reflection upon the inter-disciplinary nature of development analyses. The title of the book indicates both the original scope of its theoretical parameters, its delineation of the political dimensions of ethnicity, inequality and gender on an international scale, and the specificity of its meticulous and detailed ethnographic research. 